\title{
MOLECULAR CHARACTERIZATION OF SOME VIRULENCE GENES IN KLEBSIELLA PNEUMONIAE ISOLATED FROM BROILERS
}

\author{
ELGAOS, M.I. ${ }^{1}$; MAHMOUD, A. ABDELRAHMAN ${ }^{2}$ and AHMED, H. RAMADAN ${ }^{2}$ \\ ${ }^{1}$ Department of Poultry Diseases, Animal Health Research Institute, Mansoura Branch, Egypt. \\ ${ }^{2}$ Department of Microbiology, Animal Health Research Institute, Mansoura Branch, Egypt.
}

Received: 11 January 2019; Accepted: 5 March 2019

\begin{abstract}
In the present study, a total of 160 samples (lung, air sacs, liver and kidneys, 40 samples each) were collected from clinically diseased broiler chickens. Clinical signs were weakness, gasping, ruffled feather, nasal mucoid discharge, poor growth, facial oedema and conjunctivitis, while postmortem findings were signs of septicemia, pneumonia, air sacculitis, nephritis, sinusitis and liver and lung abscesses. Isolation and biochemical identification of $K$. pneumoniae were done. Results of bacteriological examination revealed that $K$. pneumoniae isolates were recovered from 160 samples with overall prevalence (14.4\%). The isolation rates from lung, air sacs, liver and kidneys were $30 \%, 12.5 \%, 10 \%$ and 5\%, respectively. The isolates of K. pneumoniae were found to be virulent by using PCR assay incorporating $\operatorname{magA}$, fim $\mathrm{H}$ and $\operatorname{tra\mathrm {T}}$ genes primers and were found to be resistant to some antibiotics by using PCR assay incorporating tetA(A), blaTEM and $m p h \mathrm{~A}$ genes primers. Antibiogram for 20 recovered $K$. pneumoniae isolates against 10 commercially used antibiotics in broiler chicken farms revealed that $K$. pneumoniae isolates were completey resistant to oxytetracycline $(100 \%)$ and ampicillin (100\%) followed by erythromycin (90\%), streptomycin (80\%), cefotaxim (70\%) and gentamycin (65\%) and moderate resistance to neomycin (45\%) and chloramphenicol (30\%). On the other hand $K$. pneumoniae isolates showed the lowest resistance to ciprofloxacin (20\%) and norfloxacin (10\%).
\end{abstract}

Key words: K. pneumoniae, PCR, Virulence genes, antibiotic resistance genes.

\section{INTRODUCTION}

Klebsiella species are gram-negative, encapsulated, non-motile, rod shape, lactose fermenting bacteria, belong to family Enterobacteriaceae. Members of this family are facultative anaerobic. This genus consists of 77 capsular antigens ( $\mathrm{K}$ antigens), leading to different sero-groups (Janda and Abbott, 2006). The organism expresses both O-antigen (smooth lipopolysaccharide) and K-antigen (capsular polysaccharide) and both antigens contribute to its pathogenicity. A major virulence factor of $K$. pneumoniae is the capsule, which protects Klebsiella from lethal serum factors and phagocytosis (Fung et al., 2002 and Mizuta et al., 1983).

The genomic map of $K$. pneumoniae capsule contains gene clusters as follows: $r m p \mathrm{~A}, \operatorname{rmpA} 1$ and rmpA2 (regulator of the mucoid phenotype $\mathrm{A}, \mathrm{Al}$ and $\mathrm{A} 2$, respectively), $\operatorname{mag} \mathrm{A}$ (mucoviscosity

Corresponding author: MAHMOUD, A. ABDELRAHMAN E-mail address: drmahmoudabdelnaeem81@gmail.com Present address: Department of Microbiology, Animal Health Research Institute, Mansoura Branch, Egypt. associated gene A), cps (capsular polysaccharide synthesis), $W b$ (O-specific polysaccharide is directed by the $W b$ gene cluster) (Regue et al., 2005 and Seidler et al., 1975).

The rmpA and rmpAl genes regulate the synthesis of the Klebsiella polysaccharide capsule and they are conserved in most isolates of $K$. pneumoniae. The magA gene is a part of the $K$. pneumoniae serotype $\mathrm{K} 1$ capsular polysaccharide gene cluster and contributes to the bacterial virulence (Fang et al., 2004). The magA plays an important role in serious infection of Klebsiella such as septicemia, bacteremia, pneumonia and liver and lung abscesses (Chan et al., 2005 and Chung et al., 2007). The chromosomal magA gene causes increased levels of resistance to phagocytosis and has hyperviscous phenotype, which is characterized by forming a mucoviscous string during passing loop through a colony (Struve et al., 2005).

Saif et al. (2003) related the clinical signs of weakness, gasping, oxidative pneumonia, mucoid discharge and poor egg quality and decrease egg production, pleuritis and air saculitis to Klebsiella spp. infection. 
In humans, Klebsiella spp. causing infections are often multidrug resistant and an increasing proportion of strains produce extended-spectrum beta-lactamases (ESBLs). Extended-spectrum $\beta$ lactamases confer resistance to penicillins and cephalosporins. ESBLs are most commonly detected in $K$. pneumoniae, they are plasmid-mediated enzymes, and these plasmids also carry resistance genes to other antibiotics. Thus, Gram negative bacilli containing these plasmids were multidrugresistant. In contrast, the prevalence of antimicrobial resistance in animal and poultry Klebsiella isolates was poorly documented (Jacoby, 1997).

The present study aimed to determine some virulence and antimicrobial resistance genes associated with $K$. pneumoniae infection and to Study antimicrobial resistance profile to prevent the spread of resistant $K$. pneumoniae among the diseased chickens via planning a proper control program.

\section{MATERIALS AND METHODS}

\section{Samples:}

A total of 40 clinically diseased broiler chickens were obtained from different private chicken farms in Dakahlia province and also from cases which were arrived to Mansoura Provincial Laboratory. Four samples consisting of lungs, air sacs, liver and kidneys were collected from each diseased bird. The samples were dispatched to the Laboratory without delay to be examined bacteriologically for isolation and identification of causative agent.

\section{Clinical and Postmortem examination:}

All chickens were examined clinically, then sacrified and immersed in a disinfectant before being autopsied. Gross pathological changes were recorded, summarized and presented with results for both freshly dead and clinically diseased broiler chickens.

\section{Media:}

a -Liquid media: Tryptose broth, peptone water and nutrient broth.

b- Solid media: Sheep blood agar, MacConkey's agar and Xylose lysine desoxycholate (XLD) agar (Oxoid).

\section{Isolation and identification:}

Bacterial isolation was carried out by inoculating aseptically collected samples from lungs, air sacs, liver and kidneys directly on sheep blood agar and MacConkey's agar and incubated at $37^{\circ} \mathrm{C}$ for $24-48$ hrs (Quinn et al., 1994). After incubation, colonies culture characters and morphological characters were studied. Biochemical tests including, catalase, oxidase, indole production, methyl red, VogesProskauer, citrate utilization, lysine decarboxylase, urea hydrolysis, lactose fermentation and $\mathrm{H}_{2} \mathrm{~S}$ production were used for Klebsiella spp. Identification (Trivedi et al., 2015).

\section{Molecular characterization of Klebsiella pneumoniae by PCR:}

Five $K$. pneumoniae isolates were subjected to PCR test in PCR unit in Animal Health Research Institute, AHRI according to Olivera et al. (2003).

\section{DNA extraction:}

Chromosomal DNA extraction from samples was performed using the QIAamp DNA Mini kit (Qiagen, Germany, GmbH) with modifications from the manufacturer's recommendations. Briefly, $200 \mu 1$ of the sample suspension was incubated with $10 \mu 1$ of proteinase $\mathrm{K}$ and $200 \mu \mathrm{l}$ of lysis buffer at $56^{\circ} \mathrm{C}$ for 10 min. After incubation, $200 \mu 1$ of $100 \%$ ethanol was added to the lysate. The sample was then washed and centrifuged following the manufacturer's recommendations. Nucleic acid was eluted with $100 \mu \mathrm{l}$ of elution buffer provided in the kit.

\section{Oligonucleotide Primer:}

Primers used were supplied from Metabion (Germany) are listed in table (1)

For PCR, Primers were utilized in a $25-\mu 1$ reaction containing $12.5 \mu \mathrm{l}$ of Emerald Amp Max PCR Master Mix (Takara, Japan), $1 \mu 1$ of each primer of 20 pmol concentration, $4.5 \mu \mathrm{l}$ of water, and $6 \mu 1$ of DNA template. The reaction was performed in an applied biosystem 2720 thermal cycler (Table 1).

\section{Analysis of the PCR Products:}

The products of PCR were separated by electrophoresis on 1.5\% agarose gel (Applichem, Germany, GmbH) in 1x TBE buffer at room temperature using gradients of $5 \mathrm{~V} / \mathrm{cm}$. For gel analysis, 20 $\mu 1$ of the uniplex PCR products were loaded in each gel slot. Gelpilot 100bp and 100bp plus DNA ladders (Qiagen, Germany, $\mathrm{GmbH}$ ) were used to determine the fragment sizes. The gel was photographed by a gel documentation system (Alpha Innotech, Biometra) and the data was analyzed through computer software. 
Table (1): Primers sequences, target genes, amplicon sizes and cycling conditions:

\begin{tabular}{|c|c|c|c|c|c|c|c|c|}
\hline \multirow[t]{2}{*}{ Target gene } & \multirow{2}{*}{$\begin{array}{c}\text { Primers } \\
\text { sequences } \\
\left(5^{\prime}-3^{\prime}\right)\end{array}$} & \multirow{2}{*}{$\begin{array}{l}\text { Amplified } \\
\text { segment } \\
\text { (bp) }\end{array}$} & \multirow{2}{*}{$\begin{array}{c}\text { Primary } \\
\text { denaturation }\end{array}$} & \multicolumn{3}{|c|}{ Amplification ( 35 cycles) } & \multirow{2}{*}{$\begin{array}{c}\text { Final } \\
\text { extension }\end{array}$} & \multirow[t]{2}{*}{ Reference } \\
\hline & & & & $\begin{array}{c}\text { Secondary } \\
\text { denaturation }\end{array}$ & Annealing & $\overline{\text { Extension }}$ & & \\
\hline \multirow{6}{*}{$\begin{array}{l}\text { K. pneumonia } \\
\text { 16S-23S ITS }\end{array}$} & F:ATTTGAA & 130 & $94^{\circ} \mathrm{C}$ & $94^{\circ} \mathrm{C}$ & $55^{\circ} \mathrm{C}$ & $72^{\circ} \mathrm{C}$ & $72^{\circ} \mathrm{C}$ & Turton \\
\hline & $\begin{array}{c}\text { GAGGTTGC } \\
\text { AAACGAT }\end{array}$ & & $5 \mathrm{~min}$. & $30 \mathrm{sec}$. & $30 \mathrm{sec}$. & $30 \mathrm{sec}$. & $7 \mathrm{~min}$. & $\begin{array}{l}\text { et al., } \\
2010\end{array}$ \\
\hline & $\mathbf{R}:$ TTCACTC & & & & & & & \\
\hline & TGAAGTTT & & & & & & & \\
\hline & TCTTGTGT & & & & & & & \\
\hline & & & & & & & & \\
\hline \multirow[t]{6}{*}{$\operatorname{mag} A$} & F:GGTGCTC & 1282 & $94^{\circ} \mathrm{C}$ & $94^{\circ} \mathrm{C}$ & $50^{\circ} \mathrm{C}$ & $72^{\circ} \mathrm{C}$ & $72^{\circ} \mathrm{C}$ & Yeh \\
\hline & TTTACATC & & $5 \mathrm{~min}$. & $30 \mathrm{sec}$. & $40 \mathrm{sec}$. & $1.2 \mathrm{~min}$. & $12 \mathrm{~min}$. & et al., \\
\hline & ATTGC & & & & & & & 2007 \\
\hline & R:GCAATG & & & & & & & \\
\hline & GCCATTTG & & & & & & & \\
\hline & CGTTAG & & & & & & & \\
\hline \multirow[t]{6}{*}{ fimH } & F:TGCAGA & 508 & $94^{\circ} \mathrm{C}$ & $94^{\circ} \mathrm{C}$ & $50^{\circ} \mathrm{C}$ & $72^{\circ} \mathrm{C}$ & $72^{\circ} \mathrm{C}$ & Ghanba \\
\hline & ACGGATAA & & $5 \mathrm{~min}$. & $30 \mathrm{sec}$. & $40 \mathrm{sec}$. & $45 \mathrm{sec}$. & $10 \mathrm{~min}$. & -rpour \\
\hline & GCCGTGG & & & & & & & and \\
\hline & R:GCAGTC & & & & & & & Salehi, \\
\hline & ACCTGCCC & & & & & & & 2010 \\
\hline & TCCGGTA & & & & & & & \\
\hline \multirow[t]{6}{*}{ TraT } & $\mathbf{F : G A T G G C}$ & 307 & $94^{\circ} \mathrm{C}$ & $94^{\circ} \mathrm{C}$ & $55^{\circ} \mathrm{C}$ & $72^{\circ} \mathrm{C}$ & $72^{\circ} \mathrm{C}$ & Kaipain-en \\
\hline & TGAACCGT & & $5 \mathrm{~min}$. & $30 \mathrm{sec}$. & $30 \mathrm{sec}$. & $30 \mathrm{sec}$. & $7 \mathrm{~min}$. & et al., \\
\hline & GGTTATG & & & & & & & 2002 \\
\hline & R:CACACG & & & & & & & \\
\hline & GGTCTGGT & & & & & & & \\
\hline & ATTTATGC & & & & & & & \\
\hline \multirow[t]{6}{*}{$m p h A$} & F:GTGAGG & 403 & $94^{\circ} \mathrm{C}$ & $94^{\circ} \mathrm{C}$ & $58^{\circ} \mathrm{C}$ & $72^{\circ} \mathrm{C}$ & $72^{\circ} \mathrm{C}$ & Nguyen \\
\hline & AGGAGC & & $5 \mathrm{~min}$. & $30 \mathrm{sec}$. & $40 \mathrm{sec}$. & $40 \mathrm{sec}$. & $10 \mathrm{~min}$. & et al., \\
\hline & TTCGCGAG & & & & & & & 2009 \\
\hline & R:TGCCGC & & & & & & & \\
\hline & AGGACTC & & & & & & & \\
\hline & GGAGGTC & & & & & & & \\
\hline \multirow[t]{6}{*}{$\operatorname{TetA}(A)$} & $\mathbf{F : G G T T C A C ~}$ & 576 & $94^{\circ} \mathrm{C}$ & $94^{\circ} \mathrm{C}$ & $50^{\circ} \mathrm{C}$ & $72^{\circ} \mathrm{C}$ & $72^{\circ} \mathrm{C}$ & Randall \\
\hline & TCGAAC & & $5 \mathrm{~min}$. & $30 \mathrm{sec}$. & $40 \mathrm{sec}$. & $45 \mathrm{sec}$. & $10 \mathrm{~min}$. & et al., \\
\hline & GACGTCA & & & & & & & 2004 \\
\hline & R:CTGTCC & & & & & & & \\
\hline & GACAAGT & & & & & & & \\
\hline & TGCATGA & & & & & & & \\
\hline \multirow[t]{6}{*}{ blaTEM } & $\mathbf{F}:$ ATCAGC & 516 & $94^{\circ} \mathrm{C}$ & $94^{\circ} \mathrm{C}$ & $54^{\circ} \mathrm{C}$ & $72^{\circ} \mathrm{C}$ & $72^{\circ} \mathrm{C}$ & Colom \\
\hline & AATAAA & & $5 \mathrm{~min}$. & $30 \mathrm{sec}$. & $40 \mathrm{sec}$. & $45 \mathrm{sec}$. & $10 \mathrm{~min}$. & et al., \\
\hline & CCAGC & & & & & & & 2003 \\
\hline & R:CCCCGA & & & & & & & \\
\hline & AGAACG & & & & & & & \\
\hline & тTTTC & & & & & & & \\
\hline
\end{tabular}

In vitro Antibiotic Susceptibility Test:

Twenty $K$. peumoniae isolates were subjected to antibiotic sensitivity test against 10 commonly used antibiotics in chicken farms. The antimicrobial susceptibility profile against oxytetracycline, ampicillin, erythromycin, gentamycin, streptomycin, neomycin, cefotaxim, chloramphenicol, ciprofloxacin and norfloxacin were tested by disk diffusion methods according to Clinical and Laboratory Standards Institute (CLSI, 2012).

\section{RESULTS}

Results are illustrated in tables (2-4) and figures (1-7) 
Table (2): Prevalence of $K$. peumoniae in examined broiler chickens:

\begin{tabular}{lccc}
\hline Organs & $\begin{array}{c}\text { No. of examined } \\
\text { samples }\end{array}$ & No. of positive samples & $\begin{array}{c}\text { Percentage of } \\
\text { positive samples }\end{array}$ \\
\hline Lung & 40 & 12 & $30 \%$ \\
\hline Air sacs & 40 & 5 & $12.5 \%$ \\
\hline Liver & 40 & 4 & $10 \%$ \\
\hline Kidney & 40 & 2 & $5 \%$ \\
\hline Total & 160 & 23 & $14.4 \%$ \\
\hline
\end{tabular}

Twenty K. peumoniae isolates were subjected to antibiotic sensitivity test against 10 commonly used antibiotics in chicken farms. Results are shown in table (3).

Table (3): Antibiotic sensitivity and resistance pattern for (20) K. pneumoniae isolates.

\begin{tabular}{llcccccc}
\hline & \multirow{2}{*}{ Antibiotic } & \multicolumn{2}{c}{ Sensitive } & \multicolumn{2}{c}{ Intermediate } & \multicolumn{2}{c}{ Resistant } \\
\cline { 3 - 8 } & & No. & $(\%)$ & No. & $(\%)$ & No. & $(\%)$ \\
\hline 1 & Oxytetracycline & 0 & 0 & 0 & 0 & 20 & 100 \\
\hline 2 & Ampicillin & 0 & 0 & 0 & 0 & 20 & 100 \\
\hline 3 & Erythromycin & 1 & 5 & 1 & 5 & 18 & 90 \\
\hline 4 & Streptomycin & 1 & 5 & 3 & 15 & 16 & 80 \\
\hline 5 & Cefotaxim & 2 & 10 & 4 & 20 & 14 & 70 \\
\hline 6 & Gentamycin & 2 & 10 & 5 & 25 & 13 & 65 \\
\hline 7 & Neomycin & 5 & 25 & 6 & 30 & 9 & 45 \\
\hline 8 & Chloramphenicol & 8 & 40 & 6 & 30 & 6 & 30 \\
\hline 9 & Ciprofloxacin & 11 & 55 & 5 & 25 & 4 & 20 \\
\hline 10 & Norofloxacin & 13 & 65 & 5 & 25 & 2 & 10 \\
\hline
\end{tabular}

Table (4): Results of PCR assay for detection of $K$. peumoniae virulence and antimicrobial resistance genes.

\begin{tabular}{|c|c|c|c|c|c|c|c|}
\hline \multirow[t]{3}{*}{ Isolate } & \multicolumn{7}{|c|}{ Results } \\
\hline & \multirow[t]{2}{*}{ K. pneumoniae 16S-23S ITS } & \multicolumn{3}{|c|}{ Virulence genes } & \multicolumn{3}{|c|}{ Antimicrobial resistance genes } \\
\hline & & $\operatorname{mag} \mathbf{A}$ & $\operatorname{fim} \mathbf{H}$ & $\operatorname{traT}$ & tet $\mathrm{A}$ & blaTEM & $m p h A$ \\
\hline 1 & + & + & + & + & + & + & + \\
\hline 2 & + & + & + & + & + & + & + \\
\hline 3 & + & - & + & + & + & + & + \\
\hline 4 & + & + & + & + & + & + & + \\
\hline 5 & + & + & + & + & + & + & + \\
\hline
\end{tabular}




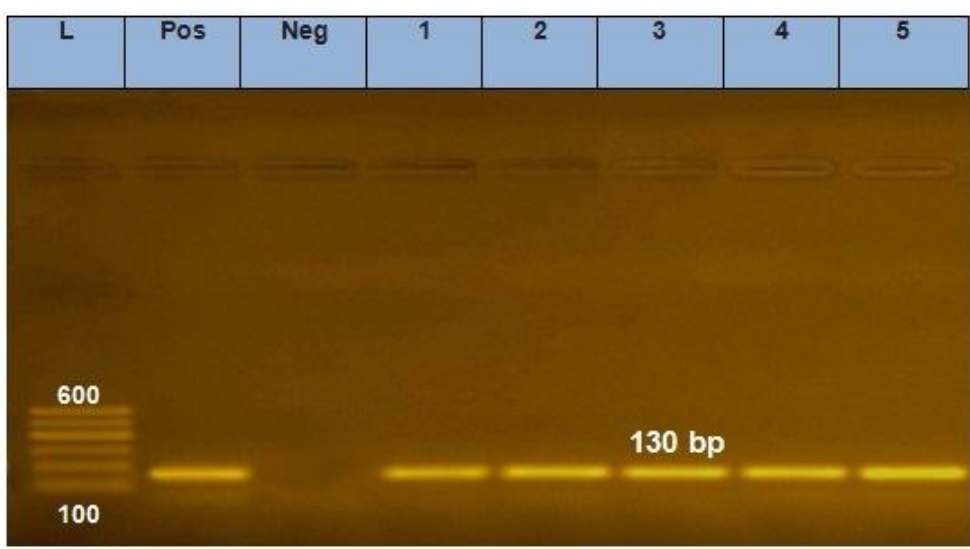

Figure (1): Agarose gel electrophoresis showing amplification of $130 \mathrm{bp}$ fragment using $16 S-23 S$ ITS primer of K. pneumoniae.

L: 100 - 600 bp ladder

Lane (1-5): Positive samples

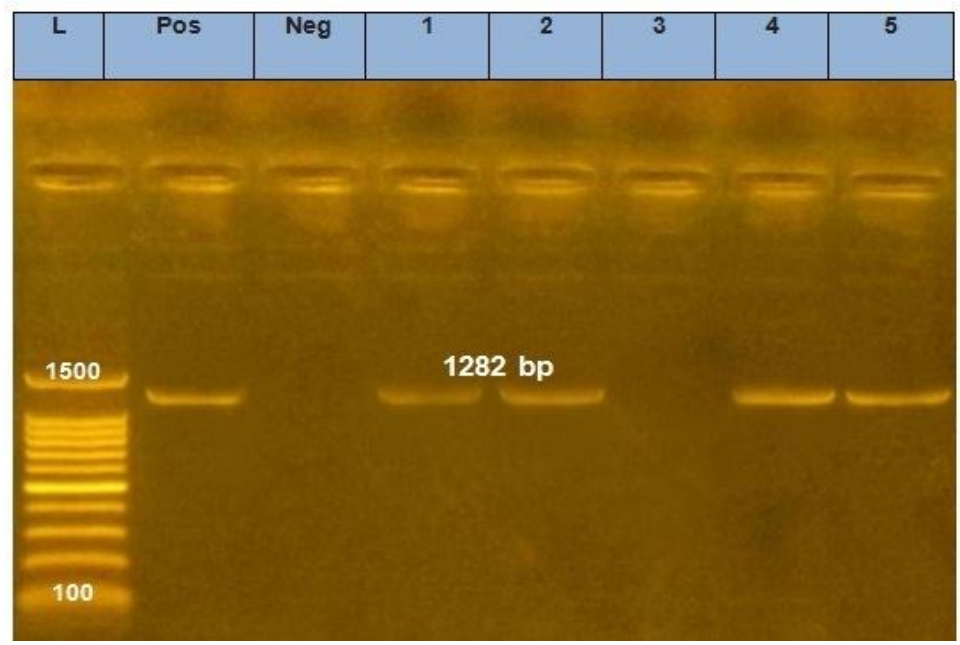

Figure (2): Agarose gel electrophoresis showing amplification of 1282 bp fragment using magA primer. L: 100 - 1500 bpladder Lane (1, 2, 4 and 5): Positive samples

Lane (3): Negative sample

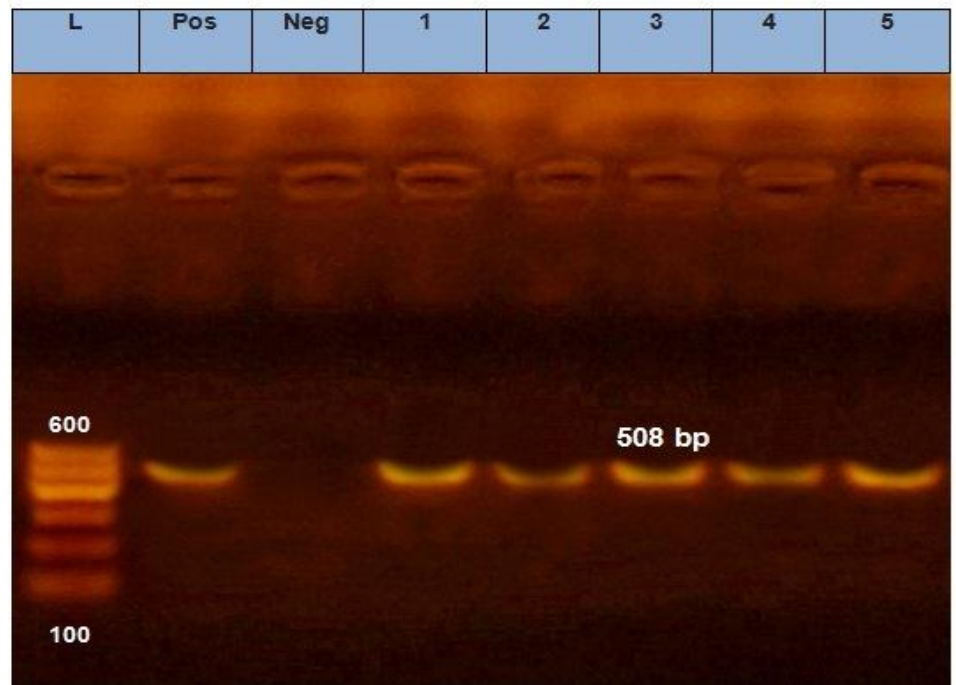

Figure (3): Agarose gel electrophoresis showing amplification of $508 \mathrm{bp}$ fragment using fim $\mathrm{H}$ primer. L: 100 - 600 bp ladder

Lane (1-5): Positive samples 


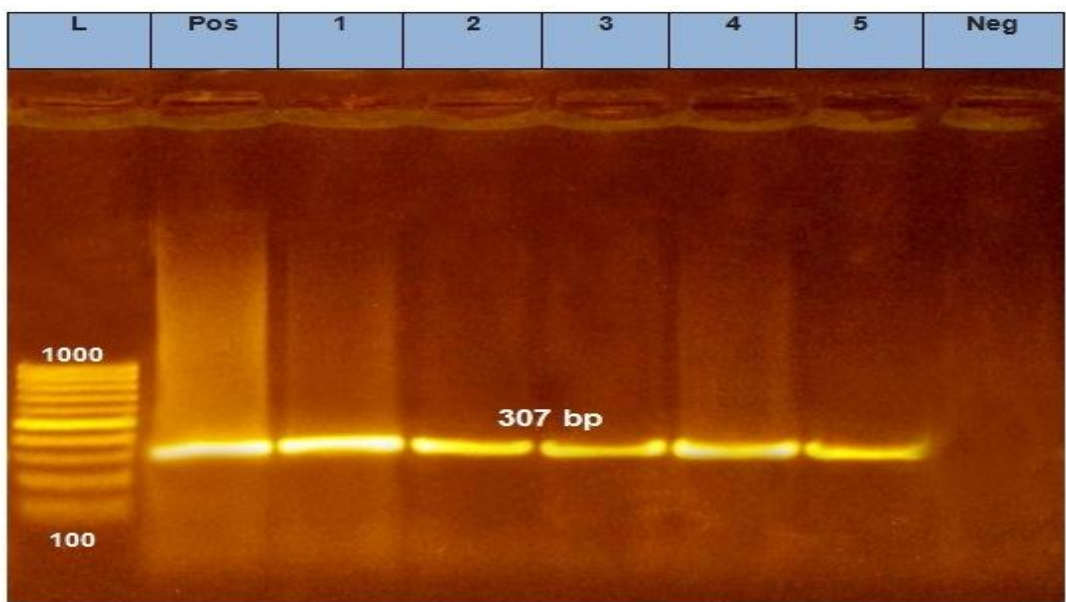

Figure (4): Agarose gel electrophoresis showing amplification of $307 \mathrm{bp}$ fragment using TraT primer. L: 100 - 1000 bp ladder Lane (1- 5): Positive sample

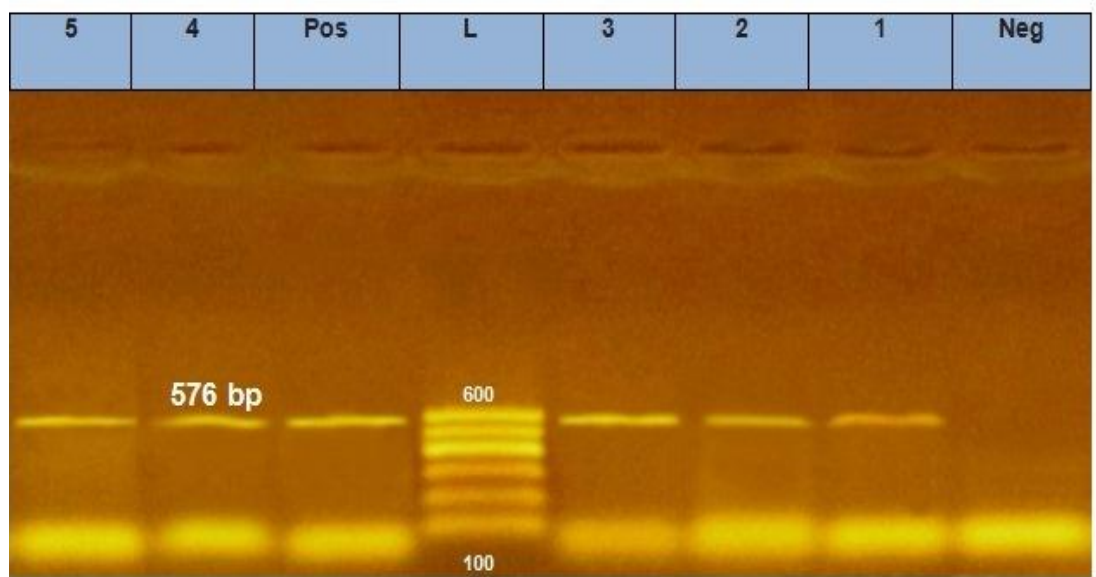

Figure (5): Agarose gel electrophoresis showing amplification of 576bp fragment using tetA (A) primer.

L: 100 - 600 bp ladder

Lane (1-5): positive samples

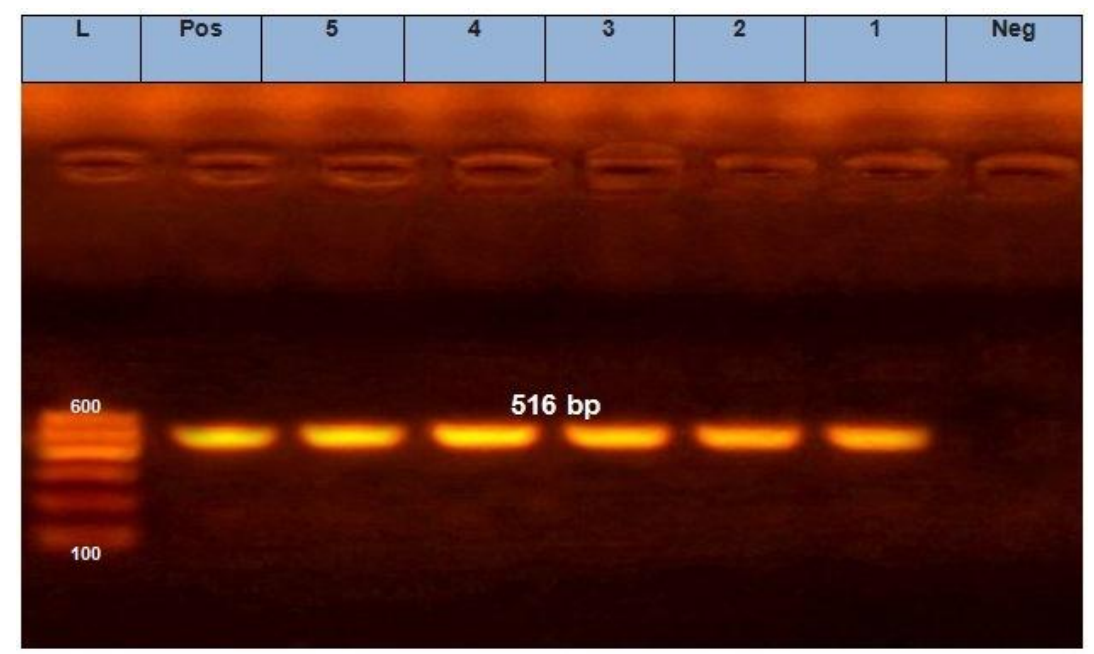

Figure (6): Agarose gel electrophoresis showing amplification of 516 bp fragment using blaTEM primer. L: 100 - 600 bp ladder

Lane (1-5): positive samples 


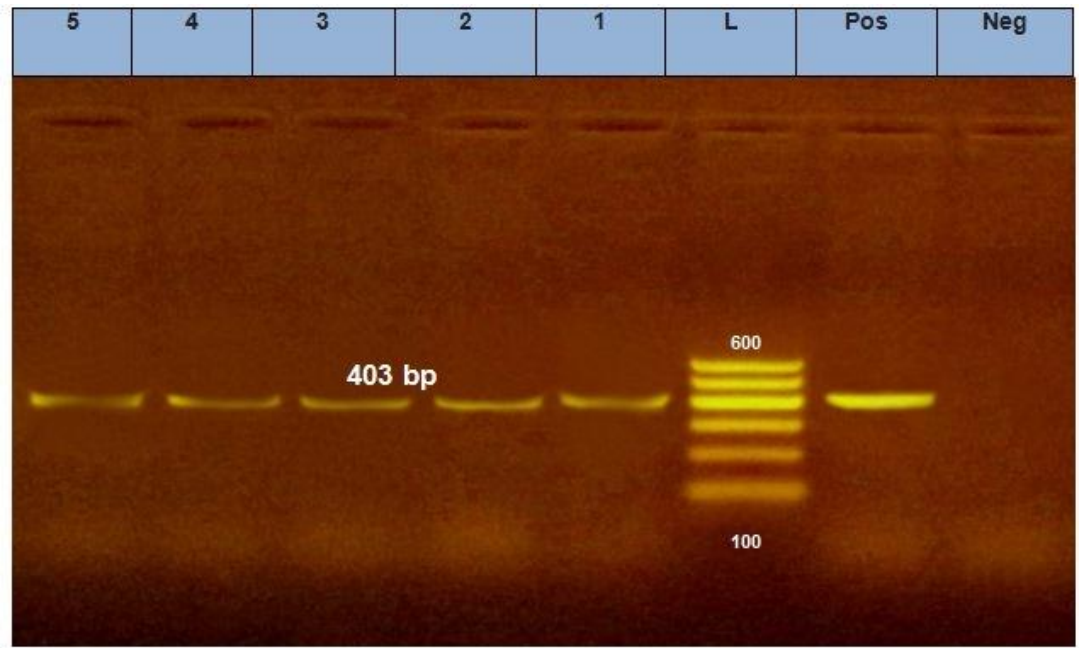

Figure (7): Agarose gel electrophoresis showing amplification of $403 \mathrm{bp}$ fragment using mphAprimer.

L: 100 - 600bp ladder

Lane (1-5): positive samples

\section{DISCUSSION}

Bacterial pathogens play an important role in causing respiratory disease in domestic poultry species (Glisson, 1998). In many cases, the bacterial pathogens colonize the respiratory system as a secondary bacterial invasion only after a primary viral or environmental insult. Klebsiella pneumoniae has been frequently recovered from birds in which it functioned as a primary pathogen and was associated with respiratory tract disease (Sandra and Duarte, 1998). Klebsiella pneumoniae infection of young poultry increased the severity of respiratory disease (Saif et al., 2003).

In the present study, the clinical findings of $K$. peumoniae infected broilers were weakness, gasping, ruffled feather, nasal mucoid discharge, poor growth, facial oedema and conjunctivitis. These findings were similar to that observed by Popy et al. (2011).

Regarding the postmortem lesions of $K$. peumoniae infected broilers, there were signs of septicemia, pneumonia, air sacculitis, nephritis, sinusitis and liver and lung abscesses. These findings agreed with that observed by Chung et al. (2007).

In general, the investigation of 160 samples collected from clinically diseased broiler chickens revealed that the prevalence rate of $K$. peumoniae was $(14.4 \%)$ as shown in (Table 2). Nearly similar results were recorded by Aly et al. (2014) and Khalda et al. (2000) who recorded that the prevalence rate of $K$. peumoniae in broiler chickens was $(10 \%)$ and $(10.2 \%)$, respectively.On the other hand, Turkyilmaz (2005) recorded a higher prevalence rate $(47.1 \%)$. Meanwhile, Dashe et al. (2013) and Abdulrazzaq et al. (2014) reported that the prevalence of $K$. peumoniae in broiler chickens was $(8 \%)$ and $(7 \%)$, respectively.
In the present study, the isolation rate of $K$. peumoniae from lungs (30\%) was higher than that of the other internal organs (air sacs, liver and kidneys, $12.5,10$ and $5 \%$, respectively) as shown in (Table 2). It was in the same direction with Younis et al. (2016).

PCR detection based on 16S-23S rDNA internal transcribed spacer (ITS) of $K$. pneumoniae was carried out in the present study. Five isolates of $K$. pneumoniae were positive to the PCR detection (Figure 1). This agree with that reported by Yin Liu et al. (2008).

PCR assay was conducted for detection of some virulence genes of $K$. pneumoniae. PCR assay could identify magA, fim $\mathrm{H}$ and $\operatorname{traT}$ genes by using specific primer sequences which yielded product sizes of $1282 \mathrm{bp}, 508 \mathrm{bp}$ and $307 \mathrm{bp}$, respectively. Out of the tested isolates, four isolates were positive and one isolate was negative for magA gene (figure 2), five isolates were positive for fim $\mathrm{H}$ gene (Figure 3) and five isolates were positive for traT gene (Figure 4). Detection of these genes may indicate the virulence potential of $K$. pneumoniae isolates. Struve et al. (2005) described magA as a novel virulence factor responsible for the increased virulence of certain $K$. pneumoniae strains. They provided evidence that the magA gene, so far believed to be a specific virulence factor in highly virulent Klebsiella strains. El Fertas et al. (2013) concluded that fim $\mathrm{H}$ gene is the most common virulence gene of $K$. pneumoniae and tra $\mathrm{T}$ gene was detected at a lower prevalence rate in $K$. pneumoniae isolates.

K. pneumoniae is an important multidrug-resistant (MDR) pathogen affecting both humans and animals. PCR assay was conducted for detection of some antimicrobial resistance genes of $K$. 
pneumoniae. PCR assay could identify tetA(A), blaTEM and $m p h \mathrm{~A}$ genes by using specific primer sequences which yielded product sizes of $576 \mathrm{bp}$, $516 \mathrm{bp}$ and $403 \mathrm{bp}$, respectively. Out of the tested isolates, five isolates were positive for tetA(A) gene (figure 5), five isolates were positive for blaTEM gene (Figure 6) and five isolates were positive for mphA gene (Figure 7). Detection of these genes may indicate the high multiple antibiotic resistances of $K$. pneumoniae isolates. Weixia Wang et al. (2014) found that the class $\mathrm{A}$ tet determinants tet(A) and tet(A)-1 could confer high-level tetracycline resistance. Ojdana et al. (2014) found that the prevalence of blaTEM genes was responsible for the production of broad-spectrum $\beta$-lactamases among $K$. pneumoniae. Soge et al. (2006) found that all the large CTX-M plasmids of $K$. pneumoniae carried several drug resistance genes including blaTEM1gene (ampicillin resistance) and tet(A) gene (tetracycline resistance) while $65 \%$ of plasmids carried $\operatorname{mph}(\mathrm{A})$ gene (macrolide resistance).

Twenty $K$. peumoniae isolates were subjected to antibiotic sensitivity test against ten commonly used antibiotics in chicken farms. All isolates were resistant to ampicillin and oxytetracyclines. This was agreed with Gundogan and Avci (2013) who reported that klebsiella species showed $100 \%$ resistant to ampicillin and Rasool et al. (2003) who found that $K$. peumoniae was resistant to tetracyclines. Brisse et al. (2006) discussed that klebsiella species were resistant to ampicillin as a result of chromosomal class-A $\beta$-Lactamase production. Also, K. peumoniae isolates showed $90 \%$ resistance rate against erythromycin. It was in agreement with that reported by Kilonzo et al. (2007). These results were supported by PCR assay which detected tetA (A), blaTEM and mphA antimicrobial resistance genes against tetracyclines, ampicillin and erythromycin, respectively. These results run parallel with that reported by Guo et al. (2016) and Hou et al. (2015). On the other hand, K. pneumoniae isolates showed moderate resistance rate $(65 \%$ and $45 \%)$ against gentamycin and neomycin, respectively. This might run parallel with Chang et al. (2000) who recorded that $K$. pneumoniae were moderately susceptible to aminoglycosides. Also, $K$. pneumoniae isolates showed lower resistance rate $(20 \%$ and $10 \%)$ against ciprofloxacin and norfloxacin, respectively. It was agreed with Gundogan and Avci (2013) who reported $23.8 \%$ resistance rate against ciprofloxacin. While, Olufemi et al. (2012) reported $(54.5 \%$ and $63.6 \%$ ) resistance rates against ciprofloxacin and norfloxacin, respectively.

\section{REFERENCES}

Abdul Razzaq, M.; Kadliim, J. Trad and AlMaaniory, A. (2014): K. pneumoniae rmpA,
rmpAl and rmpA2, Virulence Genes. Medical journal of Babylon 10:2.

Aly, M.M.; Khalil, S.A. and Metwaly, A. (2014): Isolation and molecular identification of Klebsiella microbe isolated from Chicks. AJVS.; 43(1): 97-103.

Brisse, S.R.; Grimont, F. and Grimont, P.A.D. (2006): The genus klebsiella in DWorkin M, falkow S, Rosenberg E, Schleifer K-H, Stackebrandt E, editors. The prokaryotes. A handbook on the biology of Bacteria $.3^{\text {rd }}$ edition ed. New York.

Chan, K.S.; Chen, C.M.; Cheng, K.C.; Hou, C.C.; Lin, H.J. and Yu, W.L. (2005): Pyogenic liver abscess: A retrospective analysis of 107 patients during a 3-year period. Infect Dis. 58: 366-368.

Chang, S.C.; Fang, C.T.; Hsueh, P.R.; Chen, Y.C. and Luh, K.T. (2000): Klebsiella pneumoniae isolates causing liver abscess Bagley ST (1985) Habitat association of Klebsiella species. Infect Control 6: 52-58.

Chung, D.R.; Lee, S.S.; Lee, H.R.; Kim, H.B.; Choi, H.J. and Eom, J.S. (2007): Emerging invasive liver abscess caused by K1 serotype Klebsiella pneumoniae in Korea. J. Infect. 54: 578-583.

CLSI (2012): The Clinical and Laboratory Standards Institute: Methods for dilution antimicrobial susceptibility tests for bacteria that grow aerobically; approved standard. $9^{\text {th }}$ Edition. M07-A9, 32(2).

Colom, K.; Pèrez, J.; Alonso, R.; FernándezAranguiz, A.; Lariňo, E. and Cisterna, R. (2003): Simple and reliable multiplex PCR assay for detection of blaTEM, blaSHV and blaOXA-1 genes in Enterobacteriaceae. FEMS Microbiology Letters 223 (2003) 147151.

Dashe, Y.G.; Raji, M.A.; Abdu, P.A. and Oladele, B.S. (2013): Distribution of aerobic Bacteria in visceral organs of sick and apparently healthy Chickens in Jos, Nigeria, nt.l Res. J. Microbiol. 4(3):79-83.

El Fertas-Aissani, R.; Messai, Y.; Alouache, S. and Bakour, R. (2013): Virulence profiles and antibiotic susceptibility patterns of Klebsiella pneumoniae strains isolated from different clinical specimens. Pathologie Biologie, Volume 61, Issue 5, October 2013, Pages 209-216.

Fang, C.T.; Chuang, Y.P.; Shun, C.T.; Chang, S.C. and Wang, J.T. (2004): Anovel virulence gene in Klebsiella pneumoniae strains causing primary liver abscess and septic metastatic complications. J Exp Med. 199:697-705.

Fung, C.P.; Chang, F.Y.; Lee, S.C.; Hu, B.S.; Kuo, B.I.; Liu, C.Y.; Ho, M. and Siu, L.K. (2002): A global emerging disease of Klebsiella pneumoniae liver abscess: is serotype $\mathrm{K} 1$ an 
important factor for complicated endophthalmitis. Gut. 50:420-424.

Ghanbarpour and Salehi (2010): Determination of Adhesin Encoding Genes in Escherichia coli Isolates from Omphalitis of Chicks. American Journal of Animal and Veterinary Sciences 5 (2): 91-96, 2010.

Glisson, J.R. (1998): Bacterial respiratory disease of poultry. Poult Sci.,: 77(8): 1139-42.

Gundogan, N.S. and Avci, E.R. (2013): Prevalence and antibiotic resistance of extendedspectrum beta-lactamase (ESBL) producing Escherichia coli and Klebsiella species isolated from foods of animal origin in Turkey, African Journal of Microbiology Research. Vol. 7(31), pp. 4059-4064.

Guo, Y.; Zhou, H.; Qin, L.; Pang, Z.; Qin, T.; Ren, H.; Pan, Z. and Zhou, J. (2016): Frequency, antimicrobial resistance and genetic diversity of Klebsiella pneumoniae in Food Samples. PLoS One. 2016 Apr 14:11(4): e0153561. Doi: $10.1371 /$ journal. pone. 0153561 .

Hou, X.H.; Song, X.Y.; Ma, X.B.; Zhang, S.Y. and Zhang, J.Q. (2015): Molecular characterization of multidrug-resistant Klebsiella pneumoniae isolates. Braz J Microbiol. 2015 Jul 1; 46(3):759-68. doi: 10.1590/S1517-838246320140138.

Jacoby, G.A. (1997): Extended-spectrum $\beta$ lactamases and other enzymes providing resistance to oxyimino- $\beta$-lactams. Infect. Dis. Clin., North Am., 11:875-87.

Janda, J.M. and Abbott, S.L. (2006): The Genera Klebsiella and Raoultella. The Enterobacteria $2^{\text {nd }}$ ed., pp. 115-129.

Kaipainen, T.; Pohjanvirta, T.; Shpigel, N.Y.; Shwimmer, A.; Pyörälä, S. and Pelkonen, S. (2002): Virulence factors of $E$. coli isolated from bovine clinical mastitis. Vet Microbiol. 2002 Feb 26; 85 (1): 37-46.

Khalda, A.K.; Egbal, S.A.; Rahim, LM.; El Nasri, S.O.A.; Abdelgader, B. and Jeddah, I.E. (2000): A retrospective study of poultry diseases (2000-2005) diagnosed at the department of avian disease and diagnosis, Veterinary institute (VRI), J. Am. Sci. 9 (7S).

Kilonzo-Nthenge, S.N.; Nahashon, I.F.; Chen and N. Adefope, (2007): Prevalence and Antimicrobial Resistance of Pathogenic Bacteria in chicken and guinea fowel. Poultry Science 87:1841-1848.

Mizuta, K.; Ohta, M.; Mori, M.; Hasegawa, T.; Nakashima, I. and Kato, N. (1983): Virulence for mice of Klebsiella strains belonging to the $\mathrm{O}_{1}$ group: relationship to their capsular $(\mathrm{K})$ types. Infect. Immun. 40: 56-61.

Nguyen, M.C.P.; Woerther, P.; Bouvet, M.; Andremont, A.; Leclercq, R. and Canu, A. (2009): Escherichia coli as reservoir for macrolide resistance genes. Emerging infectious diseases. Vol. 15, No. 10.
Ojdana, D.; Pawet Sacha; Piotr Wieczorek; Stawomir Czaban; Anna Michalska; Jadwiga Jaworowska; Anna Jurczak; Bogusław Poniatowski and Elżbieta Tryniszewska (2014): The Occurrence of blaCTX-M, blaSHV, and blaTEM Genes in ExtendedSpectrum $\beta$-Lactamase-Positive Strains of Klebsiella pneumoniae, Escherichia coli, and Proteus mirabilis in Poland. International Journal of Antibiotics, Volume 2014, Article ID 935842, 7 pages.

Oliveira, S.D.; Rodenbusch, C.R.; Rocha, S.L.S. and Canal, C.W. (2003): Evaluation of selective and non-selective enrichment PCR procedures for Salmonella detection. Lett. Appl. Microbiol., 36(4):217-221.

Olufemi, E.; Ojo; Olatunde, G. Ogunyinkal; Michael Agbaje and James, O. (2012): Antibiogram of Enterobacteriaceae isolated from freerange chickens. Veterinarskiarhiv 82 (6), 577-589, 2012. Turkey.

Popy, M.; Asaduzzaman, M.S.; Miah, A.; Siddika, M.A.; Sufian and Hossain, M.M. (2011): Pathological study on the upper respiratory tract infection of chickens and isolation, identification of causal bacteria. The Bangladesh Veterinarian 28(2): 60-69.

Quinn, P.J.; Carter, M.E.; Markey, B.K. and Cartey, G.E. (1994): Clinical Veterinary Microbiology. Section-2. Bacteriology, Mosby-Year Book Europe Limited, Lynton House, London, England.

Randall, L.P.; Cooles, S.W.; Osborn, M.K.; Piddock, L.J.V. and Woodward, M.J. (2004): Antibiotic resistance genes, integrons and multiple antibiotic resistance in thirty-five serotypes of Salmonella enterica isolated from humans and animals in the UK. Journal of Antimicrobial Chemotherapy.53, 208-216.

Rasool, S.A.; Ahmad, A.; Khan, S. and Wahab, A. (2003): Plasmid borne antibiotic resistance factors among indigenous Klebsiella. Pak. J. Bot. 35: 243-248.

Regue, M.; Lzquierdo, L.; Fresno, S.; Pique, N.; Corsaro, M.M. and Naldi, T. (2005): A second outer-core region in Klebsiella pneumoniae lipopolysaccharide. J. Bacteriol. 187: 4198-4206.

Saif, Y.M.; Barnes, H.J.; Glisson, J.R.; Fadly, A.M.; McDougald, L.R. and Swayne, D.E. (2003): Diseases of Poultiy $\left(11^{\text {th }}\right.$ edn.). Iowa State University Press., Blackwell Publishing Company, London, United Kingdom Pp. 849.

Sandra, O.J. and Duarte, C.J.H. (1998): Potential pathogens recovered from the upper respiratory tract of psittacine birds. File//E: Klebsiella.htm. Accessed 20/3/2008.

Seidler, R.J; Knittel, M.D. and Brown, C. (1975): Potential pathogens in the environment: cultural reactions and nucleic acid studies on Klebsiella pneumoniae from clinical and 
environmental sources. Appl. Microbiol. 29: 819-825.

Soge, O.O.; Bolanle A. Adeniyi and Marilyn C. Roberts (2006): New antibiotic resistance genes associated with CTX-M plasmids from uropathogenic Nigerian Klebsiella pneumoniae. Journal of Antimicrobial Chemotherapy, Volume 58, Issue 5, 1 November 2006, Pages 1048-1053.

Struve, C.; Bojer, M.; Nielsen, E.M.; Hansen, D.S. and Krogfelt, K.A. (2005): Investigation of the putative virulence gene magA in a world wide collection of 495 Klebsiella isolates: magA is restricted to the gene cluster of Klebsiella pneumoniae capsule serotype K 1 . J. Med Microbiol, 54: 1111-1113.

Trivedi, MK.; Branton, A.; Trivedi, D.; Gangwar, M. and Jana, S. (2015): Antimicrobial Susceptibility, Biochemical Characterization and Molecular Typing of Biofield Treated Klebsiella pneumoniae. J Health Med Inform 6: 206. doi:10.4172/2157-7420.1000206

Turkyilmaz, S.M. (2005): Isolation and serotyping of Ornithobacterium rhinotracheale from poultry. Turkish Journal of Veterinary and Animal Science, 29: 1299-1304.

Turton, J.F.; Perry, P.; Elgohari, S. and Hampton, C.V. (2010): PCR characterization and typing of Klebsiella pneumoniae using capsular type-specific, variable number tandem repeat and virulence gene targets. Journal of Medical Microbiology, 59, 541-547.

Weixia, Wang; Qinglan, Guo; Xiaogan, Xu; Zi-ke, Sheng; Xinyu, Ye and Minggui, Wang (2014): High-level tetracycline resistance mediated by efflux pumps Tet(A) and Tet(A)-1with two start codons. Journal of Medical Microbiology(2014), 63, 1454-1459.

Yeh, K.; Kurup, A.; Siu, L.K; Koh, Y.L.; Fung, C.; Lin, J.; Chen, T.; Chang, F. and Koh, T. (2007): Capsular Serotype K1 or K2, rather than magA and $\mathrm{rmpA}$, is a major virulence determinant for Klebsiella pneumoniae liver abscess in Singapore and Taiwan. J. Clin. Microbiol. 45(2): 466-471.

Yin, Liu; Chao, Liu ;Wenjie, Zheng; Xia, Zhang; Jia, Yu; Qili, Gao; and Xitai, Huang (2008): PCR detection of Klebsiella pneumoniae in infant formula based on $16 \mathrm{~S}-23 \mathrm{~S}$ internal transcribed spacer. International Journal of Food Microbiology. Volume 125, Issue 3, Pages 230-235.

Younis, G.; Awad, A.; El-Gamal, A. and Hosni, R. (2016): Virulence properties and antimicrobial susceptibility profiles of Klebsiella species recovered from clinically diseased broiler chicken. Adv. Anim. Vet. Sci. 4(10): 536-542.

\section{التوصيف الجزيئي لبعض جينات الضراوه للكلبسيلا نيموني المعزوله من بـاري التسمين

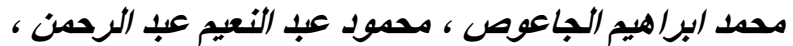

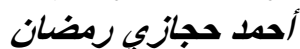

E-mail: drmahmoudabdelnaeem81@gmail.com Assiut University web-site: www.aun.edu.eg

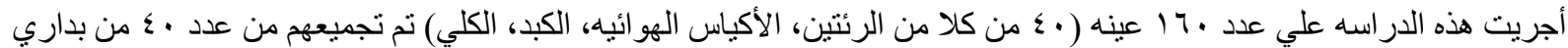

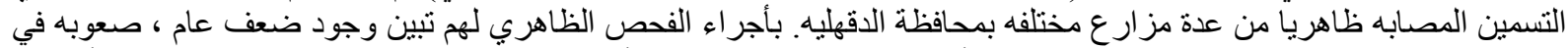

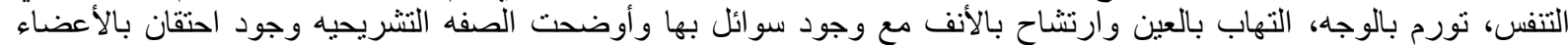

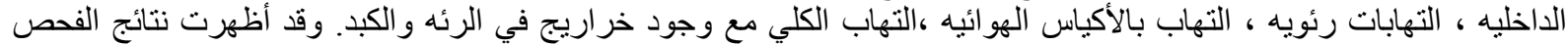

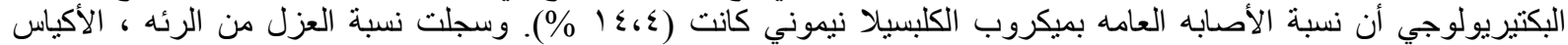

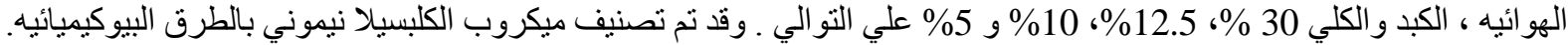

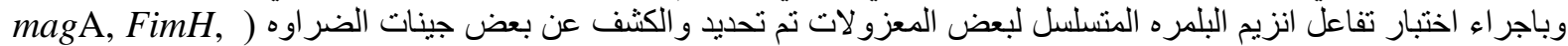

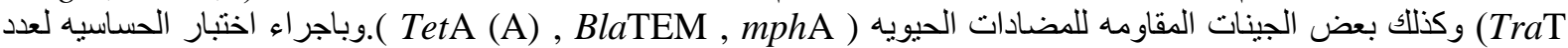

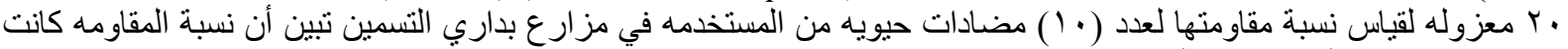

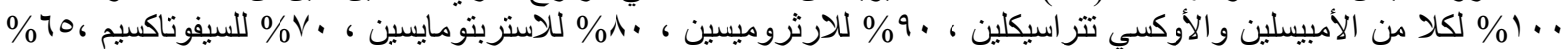

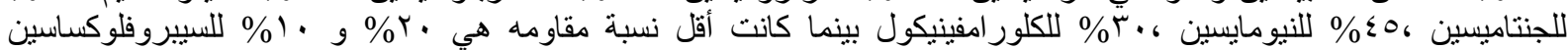
و النورفلوكساسين علي التو الي . 